\title{
A PSYCHOLOGICAl PERSPECTIVE ON THE SOURCE AND FUNCTION OF RELIGION
}

Author:

Karen van der Merwe ${ }^{1}$

\section{Affiliation:}

${ }^{1}$ Department of Psychology,

North-West University,

South Africa

\section{Correspondence to:}

Karen van der Merwe

email:

karen.vandermerwe@

nwu.ac.za

\section{Postal address:}

PO Box 1367,

Vanderbiilpark 1900,

South Africa

Keywords:

theories of religion;

worldview; meaning;

spiritual (faith)

development; religious

education

\section{Dates:}

Received: 12 Aug. 2010

Accepted: 09 Oct. 2010

Published: 22 Nov. 2010

How to cite this article:

Van der Merwe, K., 2010, 'A psychological perspective on the source and function of religion', HTS Teologiese Studies/ Theological Studies 66(1), Art. \#331, 8 pages. DOI: 10.4102/hts.v66i1.331

\section{This article is available} at:

http://www.hts.org.za

\section{Note:}

(c) 2010. The Authors. Licensee: OpenJournals Publishing. This work is licensed under the Creative Commons Attribution License.

\section{ABSTRACT}

This article explored psychological perspectives on the following: the reasons for humans' religiousness, the influence of religion on people's perspective on life and the importance of understanding the impact of religion on the lives of people. Theories, including psychoanalytical and evolutionary answers regarding the origin of human's penchant to be religious were discussed. Subsequently, the focus was on the dominant influence of religious notions in people's worldview, providing meaning and powerfully influencing their cognitions, emotions and behaviour. Finally, the importance of nurturing spiritual (faith) development was discussed.

\section{INTRODUCTION}

Most religions lay claim to exclusive answers in terms of absolute truth. However, are religions not in essence equal? From a psychological perspective, one could answer in the affirmative. Psychology has begun to research the phenomenon that religion is universally present amongst humans. Three welldocumented psychological perspectives on religion will be discussed here; however, the contribution from the field of neurology will be excluded. Attempts to explain religion are in no way aimed at invalidating some or all religions. Kirkpatrick (2005) succinctly states that

it is simply wrong to assume that a scientific understanding of why and how people come to believe in $\chi$ has any bearing on the question of whether or not $\chi$ is true.

(Kirkpatrick 2005:6)

How people's religious beliefs influence them on individual and collective levels is a question to be answered within the context of South Africa.

Traditionally, religion and spirituality were used interchangeably but since the latter half of the 20th century a schism has developed between these constructs (see Rizzuto 2005; Hill et al. 2000; Zinnbauer, Pargament \& Scott 1999 for comprehensive overviews). Both religion and spirituality have the search for the sacred at their core. However, religion is in addition associated with non-sacred goals (such as identity and belongingness) and prescribed rituals and behaviours for the search of the sacred (Hill et al. 2000). Thus, religion comprises socially constructed (cultural) beliefs and rituals, whereas spirituality entails transcendence, a psychic function that frees the individual from myopic self-absorption.

In this article, the focus is on religiousness as an objective fact of human existence (Alper 2001), but also on religiousness as cultural and personal realities. In order to gain a multidimensional understanding of the phenomenon, a scientific, inter-personal and intra-personal perspective of religiousness is explored. The construct worldview as nodal point, where the objective fact of religiousness manifests concretely in interpersonal and intrapersonal functioning is accentuated as potential source of intrapersonal discomfort and interpersonal misunderstanding. People express their religiousness in terms of various religions that centre on ideas about the absolute truth or God. Specifically, worldviews and religions that are dominant in the South African contexts are discussed, emphasising how individuals and groups create meaning within these frameworks. The focus is on Christian and traditional African worldviews because the statistics of the latest census (i.e. that of 2001) show that 79 per cent of the South African population named Christianity as their preferred religion or religious tag (Statistics South Africa 2001); the South African population is predominantly African. In the light of such a large percentage of adherers to a religion that teaches peace, honesty, neighbourly love, hard work and healthy living the prevalence of corruption, lack of care for others (service delivery) and high levels of drug and alcohol abuse is surprising. One possibility might be that South African people are religious but not spiritual. If so, what are the consequences? Possible reasons for these occurrences will be explored and the implications for educators, pastors and psychotherapists will be highlighted.

\section{THEORIES OF RELIGION}

Various psychological theories attempt to answer the question why people are religious. Generally these theories fall into three loose groups: wish-fulfilment theories, intellectualist theories and social functionalist theories (Dennet 2006; Guthrie 1993). In this article, the last two are discussed under evolutionary theories.

\section{Wish-fulfilment theories}

Freud, the father of psychoanalysis, was outspoken about his conviction that belief is mere wishfulfilment (Freud 1961). Although Darwin's theory of natural selection considerably influenced Freud's initial thinking (e.g. his life-preserving instincts and sexual instincts correspond to Darwin's theory of natural and sexual selection), he moved away from this Darwinian anchoring later in his life (Guthrie 1993). The essence of wish-fulfilment theories is the premise that religiousness is linked to feelings 
of fear and insecurity and that the function of religion is to soothe and to provide a frame of safety for believers. One could argue that the ability to allay fear provides individuals with an evolutionary advantage to explore and conquer, overpower and replicate.

Wish-fulfilment theories highlight the fact that religions provide comfort to believers, whilst fear and anxiety are alleviated by believing in a powerful Being, frequently metaphorically referred to as a Father, who is lovingly involved in the personal details of everyday life. As their God cannot be seen or experienced directly, believers acquire a concept of God according to the understandings of their religion and culture (the dominant social construction of God). However, according to Freud and Rizutto, believers shape their personal image of God through a process of identification with both parents (objects) during infancy from which parental imagos are formed. These imagos form the base of God representations (Goodwin 1998; Rizutto, 1979; Wulff 1997). Freud viewed belief in a personal God as nothing other than a representation of an exalted father, in which is embedded an infantile wish for parental protection (Goodwin 1998; Guthrie 1993; Rizutto 1979)

The developmental theory of Rizzuto (1979) in terms of the formation of God representations is embedded in psychoanalytic and object-relations theory. In her view, God representations have various components such as real life parents, wished-for parents and the feared parent of the individual's own imagining. She concludes that the formation of a God image is '... an objectrelated representational process marked by the emotional configuration of the individual prevailing at the moment he forms the representation - at any developmental stage' (Rizzuto 1979:44). God as transitional (and intentional) object undergoes transformations during the course of a believer's life and may retain its meaning, may be abandoned altogether or may be periodically revived during times of crisis. Therefore, Rizutto accentuates the dynamic nature of God representations. As humans change during their cycle of development, so too changes occur in their conceptions and images of God. A healthy parent-child relationship should lead to the development of God representations that allows for the retention and growth of faith. An example would be a representation that flows from initial positive experiences in the parent-child relationship that permit the progression of God representations from the infantile experience of 'I am held, fed and nurtured'; to the young child's experience of ' you are with me, you love me'. This belief evolves in middle childhood into 'you are my God and protector' and in adolescence into 'you are the maker of all things'. This permits a representation in young adulthood of 'you are, let me be me' and finally the late adulthood's trusting 'whatever, whoever you are, I trust you'. Mostly people are able to transform their God representations according to their needs and keep their faith throughout life. Conversely, problematic parent-child relationships could precipitate disbelief (unbelief?). A God representation that may result from cold distant parenting and leads to unbelief would be a representation that progresses from the infantile experience of 'I am not held, I feel uncared for'; to the young child's experience of 'I cannot feel you are there for me, I thought you were omnipotent, you do not love me'. In middle childhood the belief may develop into' I don't need you, ' and in adolescence into 'You are unjust, you permit evil, I don't need you '. During young adulthood the experience of 'you think I am a child, let me be' might prevail and in late adulthood the notion 'You are not there' may be the final Godrepresentation (Rizzuto 1979:206, 207).

Another theory in which parental (attachment) figures are hypothesised to be the foundation of religious belief is that of Kirkpatrick (1999, 2005) who explains religious phenomena in terms of the attachment theory (Bowlby 1980). Attachment initially develops between the primary attachment figure (mostly the mother) and child. Because of infant patterns of attachment and maternal behaviour, internal working models of attachment are patterned in the individual. Such internal working models tend to remain stable and influence adult relationships in which the other is perceived as responsive and available (such as in romantic and love relationships) (Kirkpatrick 2005). Humans, however, are imperfect attachment figures but

the idea of God is the idea of an absolutely adequate attachment figure... God is thought of as a protective and caring parent who is always reliable and always available.

(Kaufman as cited by Kirkpatrick 2005:53)

Christian and other theistic religions are premised on a personal relationship between the believer and the attachment figure (God, Jesus). Traditional beliefs in caring, guiding and chastising ancestors also involve such a relationship. This attachment system is a dynamic part of life but is acutely activated in situations of fear, illness and separation or threat of separation of the attachment figure (Kirkpatrick 1999, 2005) and motivates the believer to seek proximity in the religiously prescribed way - prayer, offerings, fasting, slaughtering an animal, or other rituals.

Psychoanalytic, object-relations and attachment theories explain belief in God as a way of fulfilling the wish for the protection of a loving, omnipotent, omniscient parent (father), which flows from and builds on the child's need for protection by a powerful other. Both the Christian conception of God as almighty Father and traditional African religions' understanding of the involvement of ancestors as mediators to God provide in this need. Ellens (1987:13) contends that humans' terror and anxiety, which result from an understanding of own finitude, is the 'driving force behind any religious quest in any religion'.

Although the explanation of religion in terms of attachment (Kirkpatrick 1999, 2005) is categorised here as a wish-fulfilment theory it can also be seen as related to an evolutionary theory of religion. Attention now turns to this theory.

\section{Evolutionary psychology: Theories of religion}

Scientific (i.e. empirically testable) explanatory theories of religion accentuate important ways in which religion and evolutionary development are interwoven. Evolutionary psychology focuses on the psychological adaptations and the by-products of these adaptations (Buss 2004). This field of enquiry concerns itself with the commonalities between people and not with individual differences; thus regarding religion, the focus is on the fact that people are religious and not on the differences between religions. Evolutionary psychology is embedded in general evolutionary theory as guiding paradigm and draws on evolutionary biology, anthropology, cognitive science, ethnology and other empirical sciences (Dennet 2006; Haidt 2006; Kirkpatrick 2005; Buss 2004; Atran 2002; Newberg, D'Aquili \& Rause 2001; Mallon \& Stich 2000).

The main features of Darwinism are variation, selection and retention (heredity). There are three products of evolution: adaptations, by-products of adaptations and noise (or random effects) (Atran 2002; Buss 2004; Kirkpatrick 2006; Tooby \& Cosmides 1990). Adaptations are 'evolved solutions to specific problems that contribute either directly or indirectly to successful reproduction' (Buss 2004:16), whilst by-products are characteristics that do not solve adaptive problems and do not have functional design, yet are coupled with adaptations that do solve problems of survival. Noise is random effects resulting from forces like mutations (Buss 2004; Tooby \& Cosmides 1990). Religiousness is seen as a by-product of multiple domainspecific cognitive adaptations, which evolved to solve problems of survival and reproduction (Dennett 2006; Kirkpatrick 2005; Atran 2002; Boyer 1994, 2001; Barrett 2000).

Evolutionary psychology understands the mind as a mental organ with domain-specific stores of information that shape and restrict preferences, sexual behaviour, emotional reactions, 
interpersonal relationships and beliefs which include religious beliefs (Mallon \& Stich 2000). How and why the mind evolved to be religious and to create religions, is the focus of intellectualist theories.

\section{Intellectualist theories}

Intellectualist theories link religiousness to a need to understand and control the world. Religions are thus systems that provide parameters within which people interpret and try to influence the world and attempt to explain the inexplicable. Religious beliefs are seen as particular ways of interpreting the world, different from, but related to secular, everyday thoughts and actions (Kirkpatrick 2005; Boyer 2001). According to Kirkpatrick (2005), eons of natural selection has produced the human brain that ensured the survival and reproduction of humans. The brain and psychological mechanisms co-evolved in the process of forging solutions to adaptive problems. Anthropologists and cognitive scientists argue that religion is a natural phenomenon that results from the evolution of various cognitive systems. It is thus a by-product of evolved cognitive adaptations (Atran 2002; Barrett 2000; Dennett 2006; Kirkpatrick 2005).

In an evolutionary framework, the link between religiousness, language and cognitive strategies is explained by focusing on the kinds of information-processing problems the human mind evolved to solve in order to survive and reproduce (Boyer 2001; Buss 2004). Language (adaptation) developed to facilitate communication and the sharing of information between individuals (Buss 2004) and leads to the ability to formulate more and more complex questions and answers about the world (Kirkpatrick 2005), life and finally about the ultimate questions regarding the origin and purpose of life. A cognitive strategy that simultaneously evolved is the ability to understand others' minds (folk psychology or intuitive psychology). This ability helps us to see others as actors with their own wishes, needs and agendas and therefore provides us with the ability to guess and predict others' thoughts and actions. Two related strategies (or cognitive tools) that evolved to fulfil humans' need for organisation and significance and for that reason were linked to religiousness as manifested in folk psychology and language will be discussed.

The first cognitive tool (universal perceptual strategy) is what Justin Barrett (Boyer 2001) calls a hyperactive agent detection device (HADD), which results in animism (attributing life to inanimate objects). It makes evolutionary sense to be hypervigilant and to treat most things as agents with their own desires and aims (Dennett 2006). Prehistorically, Homo sapiens were constantly confronted with either predators or prey. The value of the HADD lay in the advantage to over-detect agency (seeing an agent where there was none). These advantages outweighed those of under-detection (not detecting a predator or pray). Consequently, the HADD is a cognitive tool, an adaptation that enhanced Homo sapiens's ability to hunt and detect adversity and thus contributed to successful survival and reproduction. A by-product of this adaptation is the attribution of life to gods (stones, trees, sculptures and more abstract concepts and ideas of God).

The second cognitive tool is taking the intentional stance (Dennett 2006) and the resulting propensity to anthropomorphise. As conscious beings, humans live intentionally, that is, they assume an intentional stance when they hold objects and agents in their consciousness through their thoughts, intentions, plans and desires (Crane 2001). Taking the intentional stance inevitably leads to anthropomorphism (attributing human characteristics to non-human phenomena) (Boyer 2001; Guthrie 1993). Gods and spirits are represented as agents with minds, but not necessarily with human features. They have thoughts, memories and intentions (Boyer 2001). Dennett (2006) states

At the root of human belief in Gods lies the instinct on a hair trigger: the disposition to attribute agency - beliefs and desires and other mental states - to anything complicated that moves.

(Dennett 2006:114)
Whenever people make God the object of thought, an intentional object is created. The intentional object is treated as an agent with beliefs and desires (Dennett 2006), thus anthropomorphism occurs. Religious beliefs and interpretations, however, are shown to minimally and systematically violate expectations about folk physics (a person who is invisible), folk biology (a being who lives forever) and folk psychology, that is, a being who knows exactly what you think (Dennett 2006; Barrett 2000); therefore religious beliefs are described by Boyer (2001) as counterintuitive.

The human mind thus evolved various complex and interlinking cognitive strategies that include language through which ideas about God are created and shared. Most people do not fundamentally question their group's socially constructed religious ideas of God. These ideas do however also evolve over time, which ensures the God-idea of its functional, pragmatic value. Because of this flexibility of the God-idea, the notion of God is popularly described as one of the greatest human ideas of all times (Armstrong 1999).

\section{Social functionalist view}

The role of religiousness as psychological mechanisms to regulate interpersonal relationship and intra-group cooperation in order to ensure the successful reproduction of genes (Kirkpatrick 2006) is the essence of the social functionalist view.

During the evolution of Homo sapiens, individuals who formed groups and who learned to cooperate amongst themselves were able to ward off danger. Those who stuck together were the ones who successfully reproduced. These adaptations had as byproduct religion as social phenomenon, of which the purpose is to improve cooperation within human groups (Dennet 2006). A verbal promise of cooperation is not necessarily reliable, therefore a promise is not automatically worth much, but if a person demonstrates commitment through acts, such a promise is viewed as more reliable. Religion as a form of communication by means of shared acts and rituals contributes to the attribution of trustworthiness of the believers amongst themselves. The enhanced trust serves to facilitate cooperation. Religiously prescribed behaviours, badges and bans are costly means of communicating commitment to the beliefs, ideals and values in a particular religious community and strengthening coalitions (Sossis 2006). Sacrificing time and money (in other words, spending time and money in aid of the congregation), not indulging in certain activities (such as wild parties) and wearing certain clothes (a specific uniform linked to the congregation) reliably communicate a level of commitment to the in-group (Kirkpatrick 2006; Sossis 2006) and therefore trustworthiness (Atran 2002). Participation in rituals that involve all the senses (singing, rhythmic movement, consuming specific food and drink, like bread and wine) emotionally validates and cements the commitment to a shared belief in one or more supernatural agents who have full access to all information (Atran 2006). These potentially punitive agents are not deceived by overt behaviours and punish those who do not honour their commitments (Bering \& Johnson 2005). Altruism amongst kin is an evolutionary given as it secures successful transmission and survival of genes. Religious communities function as networks of fictive kin that provide major benefits to believers, for example resources (money, time, talents) that are shared to the mutual benefit of all in the congregation (Atran 2006; Nesse 1999).

The Evolutionary theories share the common assumption that there are no distinctive religious motives but rather simply religious means for satisfying irreligious human needs: survival and procreation.

The penchant to be religious thus seems to be hardwired into humans as by-product of evolutionary adaptations. Neurological processes are at the heart of consciousness through which is experienced and meaning created, however, the cultural environment patterns the way in which the brain functions 
(Lipton 2005). Nevertheless, principles and questions that guide the scientific inquiry do not provide answers to metaphysical questions of meaning which belong to another order (Gould 2001) and are reflected in culturally agreed upon renditions of reality. Positivistic science for example asks questions such as how and why humans developed to be religious, but cannot provide answers to questions such as the reason for the existence of the universe and what the purpose of being human is, thus, what the meaning of creation is. All people across the spectrum of pre-modern, modern and post-modern eras search for answers to the question of meaning. How and what is believed varies according to the cultural and religious traditions of the group.

\section{WORLDVIEWS: FRAMES FOR MEANINGS}

People want to understand themselves and the world in which they live. This quest for understanding and meaning (Frankl 1978) is ultimately a spiritual endeavour as it entails searching for meaning beyond the self, thus transcending the self. All people inhabit a personal world within which they create their individual understandings, explanations and definitions of life and the universe, which together form their worldview. A worldview is time-, place- and culture-specific (Müller 2007) and consists of ideas gleaned from ordinary people, experts, social institutions and abstractions from personal experience (Harris 2006; Koltko-Rivera 2004). Religious dogma and teachings provide ultimate answers that are integrated into people's worldviews, which contain a personal (albeit religiously informed) ontology, anthropology and cosmology. Religion provides the framework for meaning, as the quintessence of meaningfulness is connectedness with God, self and others (Leontiev 2006; Baumeister \& Vohs 2002; Post 1996).

Cosmological assumptions are ideas about the origin and nature of the universe (McLeod \& Hanks 1985) and are informed by various religious creation myths. Ontological assumptions are notions about the nature of existence and include beliefs regarding God (Packer \& Goicoechea 2000). Epistemological assumptions pertain to the nature of knowledge (inter alia revealed and scientific knowledge) of what truth is and how it can be known (Kazdin 2000; Packer \& Goicoechea 2000). These fundamental assumptions form the basis of a person's understanding of the world and life in general and are seldom questioned or examined as they are mostly unconsciously held.

\section{Worldview and religion}

Religious beliefs emanate from notions about Absolute Reality or god(s) embedded in most people's worldviews. People mainly represent $\operatorname{god}(\mathrm{s})$ as beings with human characteristics (interested in humans, loving, caring, disappointed). These beings are also thought to have some superhuman characteristics (omnipotent, all knowing, able to function outside natural laws to do miracles). Boyer (2001) describes these extraordinary features as counterintuitive, which creates an ambiguity - are these beings like humans or not? He concludes that in most groups and contexts this ontological uncertainty is neither explored nor resolved. With regard to epistemology, religious knowledge is mostly shrouded in metaphorical language and grounded in religious texts, rituals, songs and narratives and can neither be confirmed nor disconfirmed empirically (Atran 2002). Religious ideas, assumptions and beliefs are all part of a person's worldview and forms, what Pyysiäinen (2003:119) calls, a metarepresentational attitude:

Worldviews include assumptions that may be unproven, and even unprovable, but these assumptions are superordinate, in that they provide the epistemic and ontological foundations for other beliefs within a belief system.

(Koltko-Rivera 2004:3)

There certainly is a sizable group of people who might not believe in any God, but they too, due to the limitations of current knowledge, necessarily incorporate some improvable assumptions in their worldviews. Unfortunately, very few people are aware of their fundamental, unscientific assumptions that unconsciously but powerfully influence their thoughts, emotions and behaviours. These improvable assumptions about reality and ultimate reality are therefore extremely powerful. Even though they are mostly not consciously investigated by most people (Nxumalo 2004). They frame other beliefs, such as beliefs regarding how people could and should relate to god(s) and what they might expect from such beings, their own personal and collective purpose on earth and the way they should relate to those with similar and dissimilar beliefs and ethics. These beliefs provide the scaffolding for a person's uniquely created understanding of the meaning of life. Beliefs are 'principles of action' (Harris 2006:52), they not only represent people's understandings of the world but strongly guide their behaviour and can indeed be so commanding that people are willing to die or kill for them. Beliefs organise cognition, behaviour and emotions (Harris 2006; Koltko-Rivera 2004) and they relieve the insecurity of having to make sense of the unpredictability and often chaos of daily life.

\section{Multiplicity of worldviews}

As humanity evolved, different worldviews evolved in what Wilber $(2006,2007)$ calls a process of envelopment where preceding levels are included in higher levels of understanding, ethics, consciousness and ability to care. Each individual's development through different developmental stages along various developmental lines (such as cognitive, emotional, moral, interpersonal, psychosexual and spiritual) is mirrored in the collective development of societies as reflected in their worldviews or frames of meaning. Stages of development are well documented (Erikson - psychosocial development; Kohlberg moral development; Piaget - cognitive development) and follow a set sequence. All these aspects and stages of development are also reflected in the development of faith (Fowler 1981). Initially, children's point of reference is themselves and their own bodily needs and sensations (egocentric). In time, they develop to include others in an expansion of their identity from ' $\mathrm{I}$ ' to include others like themselves into the 'we' (ethnocentric). Eventually, some individuals evolve to include all other sentient beings ('all of us') in an expansion of care from the self, to the family and tribe and to the whole of humanity despite race, colour and creed (worldcentric) (Wilber 2007:45-47). The egocentric (thinking, love, morality, religion) is expanded into the ethnocentric and worldcentric, thus each successive stage contains the previous stage of development in individuals and groups. In the case of faith the most evolved stage according to Fowler (1981) represents a faith that entails a deep insight in, concern for and commitment to the universal community.

Similarly, less developed and more developed worldviews ranging from pre-secular animism through secular-dualism to post-secular holism are evident in our society (Du Toit 2006). People with a pre-secular animistic worldview are held hostage by dread due to the belief that the world is animated by a fearsome unintelligible force. Secular-dualism (also known as modernism) is linked to rationalism. Modernism represents a period of scientific advancement in which everything (humans, nature and God) became the object of investigation and analysis and resulted in the development of a schism between organised religion and science. Post-modernism is characterised by tolerance and the acknowledgement of various views and acceptance of both the physical and metaphysical (Du Toit 2006; Wilber 2006, 2007).

Although these worldviews are successive (in that they represent development), they to this day exist side by side in society. Modernity (however widespread) is not conceptualised and/or actualised in the same way in all communities, because societies are vastly different regarding their history, their way of living and basic cosmological understandings (Bastian 2001). A number of scholars therefore use the notion of multiple 
modernities, highlighting the fact that there are various discourses available about the truth (Moore \& Sanders 2001). A variety of worldviews (grand narratives) is evident in the 21st century. They are dynamic and influence each other.

The rational western worldview of modernity, which is associated with an epistemology of reason and has been shaped by a broad spectrum of philosophies and faith commitments (such as Christian and non-Christian), is prevalent in South Africa. Notwithstanding the emphasis on pure reason, many of the South African cultures are still seeped in religion - mostly Christian and traditional African religions.

\section{Christian worldviews}

Many Christians accept religious principles, prescriptions, assumptions and stories rooted in a pre-modern worldview without question. A worldview dominated by such concepts, rules and roles could be described as mythic (Wilber 2006). An example of a specific Christian worldview in die South African context is a Calvinistic worldview that is founded ' $\ldots$ on the (objective) [sic] revelation of God' (Buys 2000:21). Meaning is framed within the belief of God as the creator of all that exists and that humans are fallen sinners in need of redemption in order to enjoy a restored relationship with God. A theistic concept of a personal God who is intensely involved in the life of the individual is the dominant God concept. This Calvinistic worldview presupposes a Christian foundation for all human cultural endeavours and therefore values of love, caring and sharing are proclaimed. This view implies that '.. human thought ... is dependent on underlying presuppositions and ultimately a basic a priory religious stand' (Buys 2000:21). However, it would be a gross generalisation to assume that all Christians subscribe to this mythic worldview. Scientific developments in exegesis, hermeneutics and historical methods (Craffert 2008) have filtered down to some Christians changing their worldview from mythic to modern or even post-modern. Even within a religious paradigm, such as the Calvinistic worldview referred to above, individuals' conceptions of God will share some basic elements but will also be diverse. Religious plurality and diversity thus seems to be a dynamic characteristic of worldviews in Christian religious context. This is equally true of the worldviews in the African religious context

\section{African worldviews}

A cosmology widely found in Africa describes the world of realities as two interrelating spheres, the visible and the invisible spheres created and sustained by a Supreme Deity. African religions hold a deistic concept of God, an Omnipresent Reality, who is seldom mentioned explicitly and who is elevated above sacrifices and rituals (Kalilombe 1994, 1999). Contrary to the so-called revealed religions where theologians, specialists and laymen study and interpret holy texts, in the African oral tradition, ideas and assumptions of African religions are passed on through icons, metaphors, metonymies, dreams, visions, religious rituals, song, dance and symbols (Kalilombe 1999; Zahan 2001). In African cosmology, it is believed that powerful natural and supernatural forces (spiritual beings) govern life. This leads to a view of mystical causality where forces beyond human control are the cause of events in day-to-day life. The spiritual beings guide, protect and chastise the living (Kalu 2000; Kasambala 2005; Mbiti 1991; Zahan 2001). However, there are also evil spirits that can be kept at bay by benevolent spirits (Kasambala 2005; Nürnberger 2007).

The belief that these forces are invisible and that the forces can be neither understood nor controlled leads to elaborate rituals to protect and strengthen community members. Diviners may acquire some insight into the workings of such forces and witches and sorcerers may secretly manipulate these forces to achieve their evil aims. In African cosmology, witchcraft makes logical sense because it provides explanations for the ultimate questions of life and gives reasons for things happening as they do (Moore \& Sanders 2001). Displeased ancestors may be the cause of disease, or the disease might be a sign of the work of a witch. The diviner has to read the signs in order to understand the hidden reality that lies behind the appearances. Witchcraft also makes philosophical sense in its provision of possible answers to the big 'why' questions, thus the meaning of events and experiences. These questions cannot be answered scientifically, because even though a disease may be the result of viral infection, it is still not clear exactly why the virus infected that specific person. The questions as to the ultimate cause of things are at once ontological and cosmological and call for teleological answers, which are on a different level than scientific answers (Moore \& Sanders 2001).

Diversity characterises all human contexts; African spirituality therefore is also diverse in terms of accent and details but fundamentally, there is a strong unifying sharing of common myths. Western patterns of belief, doing and being, however, affect traditional African belief systems and can lead to adjustments and changes.

\section{The meeting of worldviews}

The worldview of an individual apparently does not change easily, if at all, at a fundamental level, because the individual's thoughts are very much controlled by culturally constructed worldviews (Wilber 2007). To some degree, individuals can transcend certain elements of their own culture. They then associate with others who share their views, thus creating a new evolved culture (Wilber 2007). Modernism brought about by colonialism and post-colonialism has progressively eroded the traditional worldview in a large portion of the more progressive African groups and individuals. A new worldview, which accentuates individual ambition and self-interest, has set people free to pursue their own success and not only that of the community (Kalilombe 1999). Although traditional values and identities may change on the conscious level, the subconscious depths of the African worldview still exert a powerful influence. In times of crises, uncertainty and uncontrollable events, many modern Africans revert to traditional beliefs and practices (Ashforth 2001; Mbiti 1999; Nxumalo 2004). As stated previously, worldviews constitute a meta-representational attitude (Pyysiäinen 2003) and provide a superordinate framework of beliefs, assumptions and personal meanings that are powerful principles of action. In any given situation, these assumptions (mostly not consciously) influence decisions and actions that affect individuals, their families and broader community.

There are congregations in every city, town and rural area where age-old (pre-modern) myths and tenets of religions are taught and reinforced. These religious communities fulfil the indispensable socio-cultural function of binding people together in groups that care for each other and provide services to their own people as well as care for out-groups, thus contributing to the health and strength of society. Religions should, however, not just fulfil a social function but also help people orientate themselves in the modern and post-modern world.

Intellectual challenges confront believers at school, university and in the broader society. They need to master a world that is dominated by science and technology: a world in which weather patterns are understood and causal factors for draughts and floods are identified (no ritual or offering changes these); where humans perform miracles (heart transplants); where information technology creates opportunities for the transfer of information never before imagined possible. The reality is that our individual and collective fate is fundamentally influenced by human decisions and actions (global warming) and people need to understand their role and function in this world - but also their responsibilities. Intellectual development is a prerequisite for people to be able to live sensibly and thrive in this world, mindful of their responsibility towards the self, other and the 
world. This would entail that people develop an internal locus of control where they believe and accept that what happens to them primarily is a result of their own behaviour and choices, as opposed to having an external locus of control where people believe that external powers and authorities determine events (Meyer \& Moore 2008). A culture of demand is enticing in that it may have the lure of easy acquisition that goes with externalising responsibility, but effectively disempowering the individual. Meaning and well-being cannot be demanded or bestowed, but are the result of individual spiritual choices.

A large proportion of children and young adults who are in formal education, come from religious backgrounds (compare census figures). They have certain (unexamined) ontological, cosmological and epistemological assumptions, which will undoubtedly affect their learning. The modern notion of knowledge creation by questioning and investigation is directly opposed to unquestioning acceptance of elders' and religious leaders' teaching. On the one hand, religious teachings reinforce pre-modern notions and some religious teachers indoctrinate followers to unquestioningly believe and accept that which they do not understand (for example the doctrine of original sin, the irreconcilability of notions of a loving caring God with the reality of human pain and suffering, the irrational notion that accidents could be caused by witchcraft). On the other hand, modern education aims at engendering cognitive (intellectual) skills, questioning, understanding and insight coupled with meta-cognitive skills. Meta-cognitive skills are such abilities as reflection on, monitoring and adjustment of own beliefs and thinking. Thus, religious teachings that are not translated into a modern or post-modern framework of cosmological and epistemological assumptions may jeopardise religions in the long run as the schism between the worldviews contained in religions and that of modern society becomes untenable and people turn away from religion because of this (Spong 2001).

The teaching of unexamined religious myths and rituals may restrain spiritual development insofar as it often induces escapism, superstitiousness, apathy, backwardness, [and] irrational outlooks on life' (Fuller 1988:48). Here the distinction between religiousness and spirituality becomes salient. Religion is a culturally accepted way by which the spirit is nurtured; according to Fowler (1981), this should ideally entail a progression between different levels of faith. The construct spirituality includes self-transcendence, a search for and reaching out to the sacred (Crossman 2003; Peterson \& Seligman 2004; Shaw 2005). The fundamental task of religion is to provide scaffolding to the spirit, via for example well-contextualised teaching, serious reflection, modelling and the opportunity for spiritual growth or growth in faith, which frequently does entail a transformation of God-concept and -image. A (theistic) concept of God as a wrathful protector of his exclusive nation or handpicked children is the breeding ground for dangerous fanaticism. Such notions divide people and may lead to intergroup and inter-personal prejudice and even violence; a situation fraught with difficulties in a multicultural country like South Africa and the global village where peoples who were previously isolated and autonomous are in constant contact with each other.

When there is a divide between intellectual and spiritual development it could be detrimental to both and therefore also to moral development (Fowler 1981). According to Fuller (1988) the primary characteristic of immature faith (stunted spiritual development) is compartmentalisation, where religion is reserved for Sundays, afterlife and for the management of existential anxiety and fear (Ellens 1987). Families and communities that do not seriously nurture religious-spiritual development run the risk of their children (and adults) falling prey to various wellbeing limiting practices such as superstitions and/or superficial ritualistic protective behaviours.

Feelings of meaninglessness may result if a spiritual connectedness is not nurtured. Some expressions of a misguided search for personal (existential) significance are consumerism, hunger for power and corruption. Spiritual (faith) development provides a life-enriching alternative: an accent on connectedness and personal improvement founded in the security of being a unique individual (significantly bolstering self-worth), loved, guided and strengthened by God (whose image may be personally defined) and being called to responsible living.

People understand, choose and give meaning in accordance with their worldviews. These fundamental beliefs are socially constructed and dominated by religious narratives, myths and teachings, as religions concern themselves with ultimate issues that cannot be established above any doubt and that are just accepted and believed. Even those tenets of religions that can and are shown by science to be indefensible (myths) are not easily shaken or discarded by believers in general. For example, scientific insights regarding for instance, the constantly evolving universe fit neither the biblical nor the African religious myths of creation (cosmology). Helping professions therefore need to be aware of the importance of religious beliefs in people's lives, whether the people they help and serve are manifestly religious or not. Helping professionals are empowered (or limited) to the degree that they understand their own and others' fundamental assumptions about life. Religious beliefs, though not necessarily in the foreground during the helping interaction, are always part of the Gestalt.

A deep spiritual connectedness to the indefinable Other provides a foundation to make life's chaos bearable and transformable. This is a very valuable frame within which pastoral counselling or psychotherapy may be conducted. However, major shifts may occur when believers can no longer overcome cognitive dissonance, which is the holding of opposing, logically inconsistent notions that results in psychic tension and anxiety (Festinger 1957), leading to disorientation and a feeling of disconnectedness from God, the self and others. The challenge to the pastor or therapist is to acknowledge the spiritual crisis and to be open to facilitate spiritual and psychological growth even if it should entail enabling a change of God-concept and eventually of God-image. A change in God-concept would entail an adjustment of the understanding of who God is and thus facilitate a new way of spiritual relatedness with God (Godimage).

\section{CONCLUSION}

Humans are bio-psycho-social-spiritual beings. Each aspect of functioning needs attention and care. Religions have the potential to contribute to the holistic development of people. Religious leaders have the responsibility to contextualise religious principles into modern and post-modern idioms and not expect people to bracket their intellectual inquisitiveness and general knowledge. In this way, they could provide guidance for people on their spiritual quest for connectedness and significance. When the central part of religion becomes but ritualistic behaviours that bind people together and keep existential anxiety at bay, religion's core spirituality is lost. Then meaning might be sought in money, power and even feelings, at whatever cost. A loss of meaning may also lead to escapism in consumerism and alcohol and drug abuse. In our predominantly religious society, societal evils are rife. This situation may in part be attributed to religious communities primarily serving a social function and fulfilling the most basic psychological needs for safety and security.

Religions all fulfil the same spiritual function - to map a road for spiritual development and to nurture and enhance spiritual maturity. Pastors and other helping professionals fail in their responsibilities if they do not acknowledge and attend to the spirituality of their charges.

Religions serve many psychological functions. They are indivisibly entwined with humans' evolution and their search 
for meaning. As humans evolve, so their beliefs need to evolve from egocentrism to world centrism, whilst this may also entail a change from absolute certainty to a tolerance of ambiguity. Dietrich Bonhoeffer's view (as quoted by Spong 2001) provides a perspective on spiritual maturity:

Our coming of age leads us to a true recognition of our situation before God. God would have us know that we must live as those who manage our lives without God. The God who is with us is the God who forsakes us. The God who lets us live in the world without the working hypothesis of God is the God before whom we stand continuously. Before God and with God we live without God.

... God is weak and powerless in the world and that is precisely the way, the only way in which he is with us to help us.

(Dietrich Bonhoeffer's as cited by Spong 2001:ix)

\section{REFERENCES}

Alper, M., 2001, The 'God' part of the brain. A scientific interpretation of human spirituality and God, Rogue Press, Brooklyn, NY

Armstrong, K., 1999, A history of God, Vintage, London.

Ashforth, A., 2001, 'On living in a world with witches: Everyday epistemology and spiritual insecurity in a modern African city (Soweto)', in H. Moore \& T. Sanders (eds.), Magical interpretations, material realities. Modernity, witchcraft and the occult in postcolonial Africa, pp. 206-225, Routledge, London.

Atran, S., 2002, In Gods we trust. The evolutionary landscape of religion, Oxford University Press, Oxford.

Atran, S., 2006, 'The cognitive and evolutionary roots of religion', in P. McNamara (ed.), Where God and sciences meet: How brain and evolutionary studies alter our understanding of religion, pp. 1-10, Praeger Publishers, Westport, CT.

Barrett, J.L., 2000, 'Exploring the natural foundations of religion', Trends in Cognitive Science 4(1), 29-34.

Bastian, M.L., 2001, 'Vulture men, campus cultists and teenage witches: modern magic in Nigerian popular media', in H.L. Moore \& T. Sanders (eds.), Magical interpretations, material realities. Modernity, witchcraft and occult in postcolonial Africa, pp. 71-117, Routledge, London.

Baumeister, R.F. \& Vohs, K.D. 2002, 'The pursuit of meaningfulness in life', in C.R. Snyder \& S.H. Lopez (eds.), Handbook of positive psychology, pp. 608-618, Oxford University Press, Oxford

Bering, J.M. \& Johnson, D.P. 2005, “'O Lord ... you perceive my thoughts from afar": Recursiveness and the evolution of supernatural agency', Journal of Cognition and Culture 5(1-2), 118-142.

Bowlby, J., 1980, Attachment and loss, Basic Books, New York.

Boyer, P., 1994, The naturalness of religious ideas. A cognitive theory of religion, University of California, Berkley.

Boyer, P., 2001, Religion explained. The evolutionary origins of religious thought, Basic Books, New York.

Buss, D.M., 2004, Evolutionary psychology. The new science of the mind, Pearson, Boston.

Buys, G., 2000, 'Competing worldviews in Africa the search for an African Christian worldview', REC Theological Forum XXVIII(3\&4), 8-27.

Craffert, P.F., 2008, The life of a Galilean shaman, Cascade Books, Eugene, OR

Crane, T., 2001, Intentional objects, Ratio 14(4), 336-349.

Crossman, J., 2003, 'Secular spiritual development in education from international and global perspectives', Oxford Review of Education 29(4), 503-520.

Degenaar, J.J., 1965, Evolusie en Christendom [Evolution and Christianity], Simondium Uitgewers, Kaapstad.

Dennett, D.C., 2006, Breaking the spell. Religion as a natural phenomenon, Allen Lane, London.

Du Toit, C.W. 2006, 'Secular spirituality versus secular dualism: Towards postsecular holism as model for a natural theology', HTS Teologiese Studies/Theological Studies 62(4), 1251-1268.
Ellens, J.H., 1987, Psychotheology: Key issues, University of South Africa, Pretoria

Festinger, L., 1957, A theory of cognitive dissonance, Stanford University Press, Stanford.

Fowler, J.W., 1981, Stages of faith, Harper, San Francisco.

Frankl, V.E., 1978, Waarom lewe ek? [Why do I live?] HAUM, Kaaptad.

Freud, S., 1961, The future of an illusion, Norton, New York.

Fuller, R.C., 1988, Religion and the life cycle, Fortress Press, Philadelphia.

Goodwin, A., 1998, 'Freud and Erikson: Their contribution to the psychology of God-image formation', Pastoral Psychology 47(2), 97-117.

Gould, S.J., 2001, Rock of ages: Science and religion in the fullness of life, Jonathan Cape, London.

Guthrie, S.E., 1993, Faces in the clouds. A new theory of religion, Oxford University Press, New York.

Haidt, J., 2006, The happiness hypothesis. Finding modern truth in ancient wisdom, Basic Books, New York.

Harris, S., 2006, The end of faith. Religion, terror, and the future of reason, Simon \& Schuster, London.

Hill, P.C., Pargament, K.I., Hood, R.W., McCullough, M.E., Swayers, J.P., Larson, D.B. \& Zinnbauer, B.J. 2000, 'Conceptualizing religion and spirituality: Points of commonality, points of departure', Journal for the Theory of Social Behaviour 30(1), 51-77.

Kalilombe, P.A., 1994, 'Spirituality in African perspective', in R. Gibellini (ed.), Paths of African theology, pp. 115-135, Orbis Books, New York.

Kalilombe, P.A., 1999, Doing theology at the grassroots. Theological essays from Malawi, Zomba, Mambo Press, Malawi.

Kalu, O.U., 2000, 'Ancestral spirituality and society in Africa', in J.O. Olupona (ed.), African spirituality. Forms, meanings and expressions, pp. 54-86, Herder and Herder, New York.

Kasambala, A.E., 2005, 'The impact of an African spirituality and cosmology on God-images in Africa: A challenge to practical theology and pastoral ministry', International Journal of Practical Theology 9(2), 300-323.

Kazdin, A.E., 2000, Encyclopedia of psychology, American Psychological Association: Oxford University Press, Washington, DC.

Kirkpatrick, L.A., 1999, 'Toward an evolutionary psychology of religion and personality', Journal of Personality 67(6), 921-952.

Kirkpatrick, L.A., 2005, Attachment, evolution, and the psychology of religion, The Guilford Press, New York.

Kirkpatrick, L.A., 2006, 'Religion is not an adaptation', in P. McNamara (ed.), Where God andsciences meet: How brain and evolutionary studies alter our understanding of religion, pp. 169-179, Praeger Publishers, Westport, CT.

Koltko-Rivera, M.E., 2004, 'The psychology of worldviews', Review of General Psychology 8(1), 3-58.

Leontiev, D., 2006, 'Meaningful living and the worlds of art', in A. Della Fave (ed.), Dimensions of well-being, pp. 529-537, FrancoAngeli, Milano.

Lipton, B.H. , 2005, The biology of belief: Unleashing the power of consciousness, matter and miracles, Mountain of Love/Elite Books, Santa Rosa, CA.

Mallon, R. \& Stich, S.P., 2000, 'The odd couple: The compatibility of social construction and the evolutionary psychology', Philosophy of Science 67, 133-154.

Mbiti, J.S., 1991, Introduction to African religion, 2nd edn., Heinemann, Blantyre.

Mbiti, J.S., 1999, African religions and philosophy, 2nd edn., Heinemann, Blantyre.

McLeod, W.T. \& Hanks, P. (eds.), 1985, The new Collins concise dictionary of the English language, Guild Publishing, London.

Meyer, W. \& Moore, C., 2008, 'Social cognitive learning approach', in W.F. Meyer, C. Moore \& H.G. Viljoen (eds.), Personology. From individual to ecosystem, 4th edn., Heinemann, Sandton. 
Moore, H. \& Sanders, T. 2001, 'Magical interpretations and material realities: An introduction', in $\mathrm{H}$. Moore \& $\mathrm{T}$. Sanders (eds.), Magical interpretations, material realities. Modernity, witchcraft and the occult in postcolonial Africa, pp. 1-27, Routledge, London.

Müller, J., 2007, "n Nuwe verstaan van God vir 'n nuwe tyd? [A new understanding of God for new times]' Beeld, 17 Oktober, pp. 8-9.

Nesse, R.M., 1999, 'The evolution of commitment and the origins of religion', Science and Spirit 10(2), 32-33, 46.

Newberg, A., D'Aquili, E. \& Rause, V., 2001, Why God won't go away. Brain science and the biology of belief, Balantine Books, New York.

Nürnberger, K., 2007, The living dead and the living God. Christ and the ancestors in a changing Africa, Cluster Publications, Pietermaritzburg.

Nxumalo, J.A., 2004, 'Pastoral ministry and African worldview', Journal of Theology for Southern Africa 28(1), 27-36.

Packer, M.J. \& Goicoechea, J., 2000, 'Sociocultural and constructivist theories of learning: Ontology, not just epistemology', Educational Psychologist 35(4), 227-241.

Pargament, K.I., 1997, The psychology of religion and coping, The Guilford Press, New York.

Peterson, C. \& Seligman, M.E.P. (eds.), 2004, Character strengths and virtues. A handbook and classification, Oxford University Press, Washington, DC.

Piedmont, R.L., 1999, 'Does spirituality represent the sixth factor of personality? Spiritual transcendence and the five-factor model', Journal of Personality 67(6), 985-1012.

Post, S.G., 1996, 'Ethics, religion, and mental health', in H.G. Koenig (ed.), Handbook of religion and mental health, pp. 21-29, Academic Publishers, San Diego.

Pyysiäinen, I., 2003, 'True fiction: Philosophy and psychology of religious belief', Philosophical Psychology 16(1), 109-125.
Rizzuto, A.-M., 1979, The birth of the living God. A psychoanalytic study, Chicago University Press, Chicago.

Rizzuto, A.-M., 2005, 'Psychoanalytical considerations about spiritually oriented psychotherapy', in L. Sperry \& E.P. Shafranske (eds.), Spiritually oriented psychotherapy, pp. 31-50, American Psychological Association, Washington, DC.

Shaw, J.A., 2005, 'A pathway to spirituality', Psychiatry 68(4), $350-362$.

Sossis, R., 2006, 'Religious behaviors, badges, and bans: Signaling theory and the evolution of religion', in P. McNamara (ed.), Where God and sciences meet: How brain and evolutionary studies alter our understanding of religion, $\mathrm{pp}$. 61-86, Praeger Publishers, Westport, CT.

Spong, J.H., 2001, A new Christianity for a new world, Harper, San Francisco.

Statistics South Africa, 2001, Primary tables South African Census '96 and 2001 compared, viewed 21 June 2006, from http:// statssa.gov.za/census01/html/RSAPrimary

Tooby, J. \& Cosmides, L., 1990, 'On the universality of human nature and the uniqueness of the individual: The role of genetic and adaptation', Journal of Personality 58(1), 17-67.

Wilber, K., 2006, The integral spirituality, Shambhala, Boston.

Wilber, K., 2007, The integral vision, Shambhala, Boston.

Wulff, D.M., 1997, Psychology of religion. Classic and contemporary, John Wiley \& Sons, New York.

Zahan, D., 2001, 'Some reflections on African spirituality', in J.K. Olupona (ed.), African spirituality. Forms, meanings and expressions, pp. 3-25, Herder and Herder, New York.

Zinnbauer, B.J., Pargament, K.I. \& Scott, A.B., 1999, 'The emerging meanings of religiousness and spirituality: Problems and Prospects', Journal of Personality 67(6), 899-918. 